\title{
Of family, futures and fear in a Balinese ward: Some preliminary thoughts toward a new project $^{1}$
}

\author{
Richard Fox \\ Ruprecht-Karls-Universität Heidelberg \\ Email:rfox@eth.uni-heidelberg.de
}

\begin{abstract}
The link between family, fear and women's bodies has a complicated history in Indonesia, tied to both international aid and economic development-as well as, in more recent years, to consumerism and transnational capital. Yet, if the 'small happy and prosperous family norm' is now the aspiration of many young Balinese, this was not always the case. Today advertisements for family planning technology encourage women to overcome fears of discomfort and physical side-effects in order to realize 'the family of their dreams'. But the fears of earlier days were not so easily allayed - incited by stories of infertility, infection and death resulting from use of the IUD. What do older Balinese remember of the early days of the KB program? How does this compare with the aspirations of younger Balinese as they pursue the pleasures of life in a 'small family' and experience its anxieties? This article presents preliminary reflections on a new project exploring how Balinese differing in gender, generation and social class talk about and act on their plans for the future. Given its importance for both state bureaucratic and commercial representations of domestic life, the ideal of the patriarchal nuclear family figures centrally in these reflections.
\end{abstract}

Key words: language, gender, family planning, futures, practical reason, Indonesia, Bali

\begin{abstract}
Abstrak
Hubungan antara keluarga, ketakutan dan tubuh perempuan memiliki sejarah yang rumit di Indonesia, terkait dengan
\end{abstract}

1 This article was originally prepared as a presentation to the second symposium on How Indonesians Argue (Deddington, Oxfordshire 25-26th. July 2016). I am grateful to Judith Fox, Mark Hobart, Ni Madé Pujawati Hobart, Michel Picard, Peter Worsley and Edmundo Luna for their thoughts and comments on earlier drafts. All errors are my own. 
bantuan internasional dan pembangunan ekonomi - dan juga, dalambeberapa tahun terakhir, terhadapkonsumerisme dan modal transnasional. Namun, jika 'norma keluarga kecil bahagia dan sejahtera' sekarang menjadi aspirasi banyak orang muda Bali, ini tidak selalu demikian. Saat ini, iklan untuk teknologi keluarga berencana mendorong wanita mengatasi ketakutan akan ketidaknyamanan dan efek samping fisik untuk mewujudkan 'keluarga impianimpian mereka'. Namun, ketakutan pada masa-masa sebelumnya tidak mudah hilang - disengaja oleh cerita tentang ketidaksuburan, infeksi dan kematian akibat penggunaan IUD. Apakah yang diingat oleh orang-orang tua Bali pada saat-saat awal program KB? Bagaimanakah ini dibandingkan dengan aspirasi orang Bali muda saat mereka mengejar kesenangan hidup di 'keluarga kecil' dan mengalami kecemasannya? Artikel ini menyajikan refleksi awal tentang sebuah proyek baru yang mengeksplorasi bagaimana perbedaan bahasa Bali dalam jenis kelamin, generasi dan kelas sosial yang membicarakan dan bertindak sesuai rencana mereka untuk masa depan. Mengingat pentingnya representasi birokrasi negara dan komersial dari kehidupan domestik, kondisi ideal dari keluarga inti patriarkal menjadi pusat dalam refleksi ini.

Kata kunci: bahasa, gender, keluarga berencana, masa depan, alasan praktis, Indonesia, Bali

\section{TV Advert for the Andalan IUD, Broadcast in 2008}

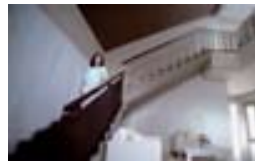

Dulu saya juga takut.

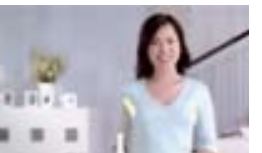

Dan saya nyaris tidak merasakan apapun.

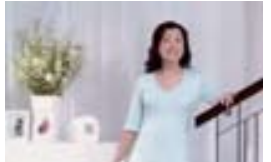

Tapi... setelah konsultasi dengan bidan Andalan...

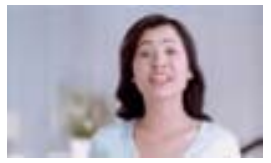

Dengan IUD Andalan saya tidak perlu memikirkan KB selama 10 tahun.

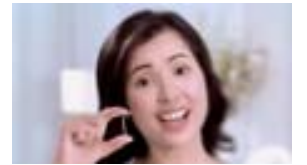

Ternyata IUD Andalan hanya sebesar ini.

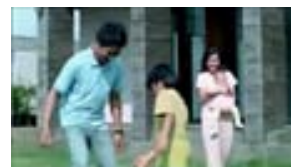

Saya hidup bahagia bersama keluarga impian saya.

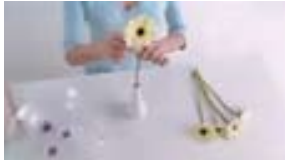

Saya memutuskan untuk menggunakannya.

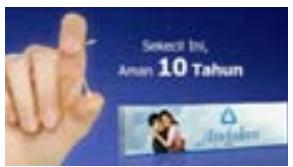

Hubungi bidan Andalan untuk informasi lebih lanjut. 


\section{Introduction}

This article offers some preliminary reflections on a project that I have recently begun, exploring how Balinese differing in gender, generation and social class talk about and act on their plans for the future-and how articulations of gender, generation and social class may be transformed in the process. The study has taken as its point of departure a collection of recorded - yet more or less informal - conversations in which Balinese reflected on what makes for a good life, how this might be realized and what obstacles may lie in the way.

Given its importance for both statebureaucratic and commercial representations of domestic life, the ideal of the patriarchal nuclear family (see, e.g., Shiraishi 1997) has figured centrally in the formulation of the project. Today the use of medical contraception, and family planning (I. keluarga berencana), is widely associated with 'modernity' (I. kemodérnan) and a progressive outlook that aims to transcend the perceived backwardness of village life (e.g., as kampungan, or tertinggal). ${ }^{2}$ The television advertisement depicted above exemplifies the commercial articulation of this ideal, bringing together a vision of patriarchal domesticity with hopes for an affluent and secure future (I. "Aman 10 tahun"), as afforded by the techno-medical management of women's bodies.

Issues of expense aside, stories of pain and discomfort, and of adverse side-effects from contraception circulate widely among women in Bali, as elsewhere. Accordingly, visits to the clinic, or to the doctor, are often accompanied by apprehension. It is perhaps with this in mind that fear is inoculated (Barthes 1972) in the opening frames of the advertisement. Dressed smartly, if casually, a light-skinned and attractive young woman addresses the viewers directly. Speaking from within an elegant home, she confides that she was once like us: 'Before, I too was afraid' (I. Dulu saya juga takut). But she then goes on to explain that, having consulted the midwife from Andalan, ${ }^{3}$ it turned out the IUD was small enough to

2 There are also countercurrents that see the two-child family as reflecting undue pressure from the government, or from a wider Indonesian culture at odds with Balinese tradition. Some have spoken, for instance, of 'KB Bali', by which is meant the full complement of four children-allowing for the use of each of the birth-order names, from Wayan/Gdé/Putu to Ketut.

3 Andalan is a brand associated with DKT-Indonesia, which the Center for 
be held between her fingers. Once cut to size - like the flower she is shown clipping for a vase - 'I could hardly feel a thing' (I. saya nyaris tidak merasakan apapun).

The link between family, fear and women's bodies has a complicated history in Indonesia, tied to both international aid and economic development (see Appendix) and, in more recent years, to consumerism and transnational capital. Yet, if the 'small happy and prosperous family norm' is now the aspiration of many young Balinese (I. norma keluarga kecil, bahagia dan sejahtera; see Newland 2001), this was not always the case. The Andalan advertisement encourages women to overcome fears of discomfort, and perhaps physical side-effects, in order to realize 'the family of their dreams' (I. keluarga impian). But the fears of earlier days were not so easily allayed, incited by stories of infertility, infection and death resulting from use of the IUD. As an assemblage of instruments, institutions and procedures, 'the family' at that time was anything but an experience of 'happiness and prosperity'. One of the project's central aims is to explore the transformation of this object of fear into one of desire. What do older Balinese remember of the early days of the KB program? How does this compare with the aspirations of younger Balinese as they pursue the pleasures of life in a 'small family' and experience its anxieties? What new forms of intimacy, embodiment and achievement are characteristic of this ideal? Through what sorts of practices are the requisite virtues cultivated? And what are some of the more important antagonisms that arise as a consequence?

Many of the issues involved are seen to be relatively sensitive, and so not especially easy to discuss casually with a foreign researcher. ${ }^{4}$ For this reason I have enlisted the assistance of Madé

Health Market Innovations describes as 'the largest private family planning program in the world' (http://healthmarketinnovations .org/program/ andalan-dkt-indonesia; accessed 2016.06.17).

4 The question is not so much one of modesty or privacy, but rather of tailoring remarks (e.g., 'dumbing down' or simplifying) for my benefit. As one of my primary interests is the style of speaking, and of arguing, such tailoring is clearly an issue. By recording a conversation between Balinese in my absence, I certainly do not mean to suggest that I am getting to the truth of whatever is being discussed-a fortiori as all parties are aware they are being recorded, and for whom. Rather my aim is to get a better sense of how certain Balinese speak to one another, often as in the presence of specific 
Dani-a young woman with whom I've worked on previous projects - to conduct a series of informal conversations, which she has both recorded and transcribed. ${ }^{5}$ We have subsequently worked together on refining the transcriptions and discussing their contents, both on our own and with others. As the research progresses I expect to be more directly involved in many of the conversations - in the first instance by following up on these initial recordings. I should add that the project itself has grown out of similar conversations that I have found myself involved in over the past several years while pursuing research on other topics. ${ }^{6}$

\section{Two Sets of Conversations}

To date we have worked on two sets of conversations recorded in 2013 and 2015 respectively: (i) the first with a group of older women, between the ages of 45 and 75, reflecting on their experience of the family planning program (I. keluarga berencana) as it was introduced in the ward of Batan Nangka (see below) in the 1970s and 80s; (ii) the second with a group of teenagers and young adults discussing their plans for the future, with a special emphasis on their hopes for employment, romance and domestic life, and how they plan to realize these desires. ${ }^{7}$ If the idea of the family is central to the aspirations of many among today's youth, it would appear that its introduction to the older generation was accompanied by the uncertainty and fear that attended many government programs promulgated after the communist purges of 1965-66.

The following discussion draws mainly on a series of conversations with a group of five older women from a single

other Balinese.

5 All names of persons and places are pseudonymous, apart from well-known locations in and around the provincial capital of Denpasar (e.g., Abian Kapas).

6 The first of these conversations that I can recall was with Dani herself, when she discussed with great feeling her desire to purchase a home in which she might live 'independently' with her husband and children, away from the natal home where she was about to be married as a jural male, and so heir to her father's line (see Fox forthcoming $a$ ).

7 The English word 'planning' figured prominently in these initial conversations with younger Balinese - both in Balinese and Indonesian phrases - alongside related terms such as body, studi, (ber)komitmén, ekonomi, hobi, bisnis, program and target. 
extended family, focusing in particular on their use of language and, for lack of a better phrase, their style of argumentation. ${ }^{8}$ I shall return at the end to make a series of provisional comparisons with the younger cohort, and review a few of what I take to be the more important questions suggested by the comparison.

\section{A Few Lines of Enquiry}

The project carries forward a broader interest in what I have been calling styles of practical reasoning. By this I mean, in the first instance, those forms of deliberation through which means and ends are evaluated and decisions to act are taken. But it also includes, more generally, the ways in which people set about embodying, cultivating and contesting shared ideals of agency, community and the common good. The interest in practical reasoning is driven by the idea that a rigorously critical approach to practice would preclude the sort of reification characteristic of prevailing 'practice theory' (e.g., Bourdieu, Giddens and Schatzki, but quite possibly Foucault and Butler, too; see Fox, forthcoming $b$ ). One of the project's theoretical aims is to begin rethinking social life in a more dynamic idiom. The question is whether one might formulate a pragmatic approach to argument that avoids reifying practice as an 'object of study'. ${ }^{9}$

It was with this, and a related set of questions, in mind that I began looking into Balinese desires for the future-now increasingly with an emphasis on argument as a form of thought in motion. Here Balinese representations of human flourishing and collective life might be seen as directed to bringing about - or, alternatively, forestalling - a specified set of events and circumstances. Under this description, articulations of such things as family and belonging, personal transformation and accomplishment, safety and sustenance, would emerge as prospective trajectories heading off into a time yet to come. One advantage to such a mobile metaphor

8 I had originally intended to discuss both sets of conversations in equal measure. But, for reasons that will become apparent, explicating even the short five-minute excerpt below proved exceedingly complicated.

9 Here I think we would need to distinguish between reification on our own part (which I would like to avoid), and the way certain activities are reified by those with whom we are working (e.g., when Balinese speak of agama, or of maintaining a houseyard, as something like a 'practice'). 
is that it might be less susceptible to objectification than our more habitual uses of 'society' and 'culture', which inter alia predispose us to hypostatize social transformation as a sequence of stable states. ${ }^{10}$ On this more radically pragmatic approach, the utterances one encounters in the course of ethnographic conversation may be recognized as contributing to an argument on its way - as a 'project', or a throwing forward, that reworks and transforms precedent, under a given set of circumstances, with an eye to bringing about a particular kind of future.

Taking 'the future' as argument - or as partially constitutive of an argument - raises some difficult questions, not least when it comes to transcribing ethnographic dialogue. The technical challenges alone are 'hellishly difficult', as Fabian put it (1990: 88). And in just a moment I'll have a few words to say about the difficulties I've encountered in trying to come to grips with the recorded conversations in colloquial Balinese. But first, more generally speaking, it is worth pausing briefly to reflect on the way ethnographic transcriptions tend to presuppose the reducibility of utterances to 'what was said' - which, even when not exhaustively equated with an ostensibly 'propositional content', leaves out much - often of great importance - that will have taken place on the occasion. Under what conditions, for instance, is one able to discern and represent those aspects of conversation that Austin (1975) described in terms of illocutionary and perlocutionary force? And,

10 This is an important connection, and perhaps I am moving ahead too quickly. What I wish to say, in short, is that our received critical apparatus is geared to stasis, as exemplified by standard scholarly uses of terms such as society, culture and the subject. These terms - and the lines of questioning they embody - engender a crucial displacement, whereby evanescent events are transformed into things, while the tenuous assemblages they articulate are unduly stabilized as knowable states (e.g., social structures, cultural formations, systems of belief, the discourse on ' $x$ '). Social 'change' is accordingly construed as a sequence of such states. And yet, to the extent that 'change' is characterized by movement, it remains inexplicable. For such an episodic account cannot accommodate the processual nature of historical transformation without reducing it to a sequence of bounded moments. Here the problem derives, at least in part, from presupposing what is ultimately a visualist account of knowledge (Fabian 1983; cp. Ong 1958), founded on the hypostatizing tropes of spatiality and distance. My theoretical interest in 'the future' is impelled by a desire to think otherwise. And the analysis of utterances - and of speaking - albeit engendering a potentially misleading textualization, is directed to this end. 
recalling the optative character of remarks on the future, to what extent should we take statements of desire as directed to realizing, exemplifying or even dissimulating that very desire?

Much of the work carried out by anthropologists and others of an ethnographic bent would be impossible without first transcribing recorded conversations. And yet, if my experience with this new project were anything to go by, there is a very real possibility that the results of transcription are often systematically misleading. For instance, in reviewing the transcripts with Dani, a written sequence of loosely linked clauses often appeared to suggest a degree of incoherence, or uncertainty, that would not have been apparent to participants in the conversation. Similarly, while the appearance of repetition in written form may seem to express reticence, or confusion, even the most cursory review of the corresponding recording has often borne out evidence of a quite different affectsuch as emphasis, urgency or even distress at the thought of the events recounted. These issues would, I think, be pertinent for anyone engaged in research that involves the speech of others. But they seem all the more pressing given my interest - and that of several of my colleagues - in the idea of argument. ${ }^{11}$

\section{Briefly on Banjar Batan Nangka}

The study itself is based in Batan Nangka, a southern Balinese ward in which I have conducted some two years' prior fieldwork. I have elsewhere (Fox 2016) described the community and its environs as follows: Batan Nangka is one of seven wards that make up the 'traditional village' (B. désa pakraman) of Pateluan, itself also a pseudonym. The ward comprises 108 family households (B. kuren; I. keluarga) living in 71 houseyards (B. pakarangan), with a total reported population of around 480 at the time of the 2011 census. In matters of marriage and inheritance Batan Nangka is very generally similar to other southerly Balinese wards as described in the anthropological literature (see, e.g., Geertz and Geertz 1975, Hobart 1979; cp. Korn 1932). Although strictly speaking the banjar is not a territorial designation, the vast majority of Batan Nangka's houseyards occupy a continuous stretch of land measuring approximately 11 hectares. On the south and west, this central concentration of

11 See footnote 1. 
houseyards is bordered by rice fields and dry agricultural land (B. tegal). The easternmost houseyards abut on a ravine through which a river runs from north to south; and the northernmost houseyards (with but a few exceptions) are situated along the southern side of a major road running from the semi-urban village of Adan Palsu in the west (population approximately 5500) to the main thoroughfare of Jalan Raya Kaneraka. The latter runs north to the comparatively rural Administrative Village of Mogbog Gdé, and south toward the provincial capital of Denpasar. The economy of Batan Nangka is mixed, with most households generating a living from a combination of small-scale agriculture, informal labor and salaried work. Although there is a limited number of 'newcomers' (I. pendudukpendatang) residing in the community, the vast majority of those living in Batan Nangka are from extended families that have made their homes there for several generations. Many in the banjar community own and work rice land that is not directly contiguous with the area of Batan Nangka. Others own no rice land at all, having sold it (e.g., to pay debts incurred through gambling or the sponsorship of ceremonial rites) or given it up when moving to a new houseyard (B, ngarangin) without rice land attached to it.

\section{Notes on Language}

As one might expect, styles of speaking in Batan Nangka vary along lines of gender, generation and social class, as well as according to circumstance. ${ }^{12}$ These are distinctions I hope to develop further in the course of the research. The interplay between Balinese and Indonesian is, in very general terms, similar to tendencies encountered elsewhere on the island (see Zurbuchen 1984), and beyond (Errington 1998). But the use of Balinese in particular also exhibits certain features that, if not unique, are locally recognized as characteristic of the way people speak in the wider village of Pateluan and the surrounding area. As a preface to examining in some detail an excerpt from one of Dani's conversations, the following sections on language provide some introductory notes on: (a) how otherwise Balinese conversation incorporates Indonesian terms and phrases; (b) local variations on 'standard' Balinese; (c) the importance of pretext and the relativity of reference,

12 Styles of speaking are, of course, also constitutive of these distinctions. 
particularly regarding people, places and occasions; and (d) the use of direct speech in recounting past events. These introductory notes are meant to facilitate a close reading of the longer transcript to follow.

\section{Language: Balinese Articulates Indonesian Terms}

In casual conversation among the older residents of Batan Nangka, Balinese tends to dominate as the language of articulation, linking together otherwise isolated words and phrases in the national language of Indonesian. ${ }^{13}$ The following example is taken from the beginning of Dani's first conversation for the project, which she conducted with her mother ('Mémék'), who was in her late 40s at the time. Originally from a beachside tourist town in the south, Mémék moved to Batan Nangka in her early 20s, when she married Dani's father. After high school she earned a certificate in religious education (I. pendidikan agama), which qualifies her to teach at elementary school; but she now runs a warung at the front of the houseyard, and goes to market to sell vegetables several mornings each week. Reported direct speech is in blue; Balinese is in ordinary roman script; Indonesian terms are underlined.

\begin{tabular}{|c|c|c|}
\hline Dani & $\begin{array}{l}\text { Uh apa adan-né... Mémék } \\
\text { nganggo } \underline{\text { KB }} \text { uli pidan? }{ }^{14}\end{array}$ & $\begin{array}{l}\text { So uh what's it called... since } \\
\text { when've you been using } \underline{\mathrm{KB}} \\
\text { (keluarga berencana,'family } \\
\text { planning'), mum? }\end{array}$ \\
\hline Mémék & $\begin{array}{l}\text { Uli... Heny ... uh... Tahun } \\
\text { kuda ya 'to? Delapan ... uaa. }\end{array}$ & $\begin{array}{l}\text { Since... Heny } \ldots \text { uh... What year } \\
\text { was that? Eighty ... two }{ }^{15}\end{array}$ \\
\hline
\end{tabular}

13 The interplay of Balinese and Indonesian seems rather more complicated among the younger generations. It is also worth mentioning that older men tend to speak Balinese in a manner that is more overtly inflected by Indonesian speech patterns than do women of the same age.

14 Balinese words are transcribed in standard roman script; Indonesian is underlined. Although it is impossible to match up the words in the transcript and gloss on a one-to-one basis, I've tried to specify where each of these registers occurs. Three dots ... indicates a pause, or an incomplete sentence. Three dots between brackets [...] indicates an elision.

15 Heny is the youngest of her four children. It seems Dani's mother was thinking aloud, and did not finish the thought, perhaps calculating back from Heny's birth. 


\begin{tabular}{|c|c|c|}
\hline Dani & $\begin{array}{l}\text { Yan menurut 'Mek 'to, } \underline{\mathrm{KB}} \\
\text { 'to apa } \underline{\mathrm{sih}} \text { ? Adi } \underline{\mathrm{KB}} \text { 'to } \underline{\text { kayak }} \\
\text { 'né penting 'ja anggon... } \\
\text { 'nak yen 'ba ngelah panak? }\end{array}$ & 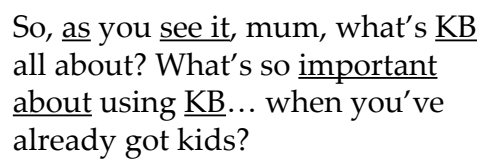 \\
\hline Mémék & $\begin{array}{l}\text { Uh... } \underline{\mathrm{KB}} \underline{\mathrm{kan}} \text { anggon } \\
\text { menunda kehamilan.... } \\
\text { Men sing meKB sih terus ya } \\
\text { beling toh. }\end{array}$ & $\begin{array}{l}\text { Uh... } \underline{\mathrm{KB}} \text { 's for delaying } \\
\text { pregnancy, } \underline{\text { isn't it. Coz if you're }} \\
\text { not using } \underline{\mathrm{KB}} \text { you'll be pregnant all } \\
\text { the time. }\end{array}$ \\
\hline Dani & $\begin{array}{l}\text { Mémék nawang } \underline{\mathrm{KB}} \text { `to... uli } \\
\text { dija? }\end{array}$ & $\begin{array}{l}\text { Where'd... ya hear about } \underline{\mathrm{KB}} \text {, } \\
\text { mum? }\end{array}$ \\
\hline Mémék & 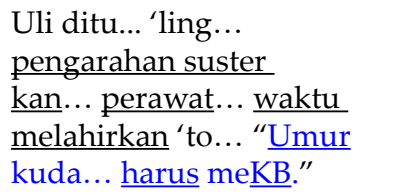 & $\begin{array}{l}\text { From there... from... instructions } \\
\text { from the sister, wasn't it, the } \\
\text { nurse... back when giving birth. } \\
\text { "At such an age... you must be on } \\
\text { KB." }\end{array}$ \\
\hline
\end{tabular}

Although Mémék is younger than the others from the older cohort, and has undergone more extensive education, the relationship between Indonesian and Balinese in her conversation with Dani reflects more general trends across the initial five conversations, including:

- The questions and main clauses are mostly phrased in colloquial Balinese;

- But many of the Balinese constructions incorporate Indonesian elements (e.g., Yan menurut 'Mek 'to...);

- There are also Indonesian constructions that incorporate Balinese terms (e.g., waktu melahirkan 'to);

- Both Indonesian ( $\underline{\operatorname{sih}} \underline{\text { kan}}$ ) and Balinese (toh) emphatic particles are used;

- Direct speech is employed extensively in recounting past events (see below for more illustrative examples);

- Though not especially evident here, there is also a degree of register-shifting that occurs according to topic. So, for instance, factual discussion of government programs is more strongly inflected by Indonesian (seemingly both in syntax and diction), while one's experience of these programs is more commonly articulated in Balinese-as is borne out in the extended example below (see section entitled 'Fear and loathing'). Albeit evident in conversation with both the 
younger and older cohorts, when and how these shifts occur may differ significantly (e.g., according to age etc.).

As one might expect, older people used less Indonesian in otherwise informal Balinese conversation. This tended to come in the form of isolated technical terms (e.g., suntik, pemerintah, klinik) and commonly used phrases (e.g., suntik satu bulan). As with the colloquial Balinese spoken today more generally, Indonesian base words are often employed within an otherwise Balinese morphology (e.g., maperasi [ma-operasi], masuntik, ma- $\underline{K B}$; but also akhir-né and soal-né; compare younger generations' use of terms such as ngefésbuk ['to use Facebook'], ngebél ['to ring', or 'call']). In passing it is worth noting a certain affinity with the juxtaposition of linguistic registers in palm-leaf 'how-to' manuals for ceremonial rites, in which Balinese base words are given what appears to be a prestige-lifting Old Javanese inflection, and Old Javanese words may conversely be 'domesticated' by the addition of Balinese affixes. It is also quite common in the extemporized dialogue of Balinese drama, where Indonesian terms are given Balinese affixes and pronunciation, and vice versa.

\section{Language: Very Briefly on Pronunciation}

Spoken Balinese varies to some degree from banjar to banjar, though certain differences from 'standard' Balinese are also recognized locally as characteristic of Pateluan and its neighboring villages. Some of the more prominent examples include the following:

- -ng is often used in place of a final -n; so kewénténang for standard kewéntenan.

- $/ \mathrm{n} /$ is often elided in both demonstrative and possessive endings that would ordinarily be pronounced -né; so manusa-é and kopi-é for standard manusa-né and kopi-né.

- Often the -é ending is pronounced " $\breve{~ " ”, ~ o r ~ e v e n ~ m o r e ~ s t r o n g l y, ~}$ as with the standard pronunciation of a final $-\mathrm{a}$; the vowel may also be drawn out for particular effect (e.g., after a name it may be disparaging - "Kadék-aaa..." "that Kadék...").

Also note that, throughout the transcripts, I have marked /e/ as -é for the vowel that would be marked with a taléng in Balinese script; the unmarked /e/ in my text corresponds to the vowel 
marked with a pĕpĕt.

\section{Language: 'Pretext' and the Relativity of Reference}

One aspect of otherwise casual conversation that would have been most recognizably affected by my direct involvement was pretextand particularly shared points of reference including people, places and occasions. With regard to people, kinship terms (e.g., 'Wa, 'Dong, Mbok) are used in reference both to oneself and others, often including a direct interlocutor, in ways that are exceedingly difficult to follow for those who are not longstanding members of the community. ${ }^{16}$ Similarly, directional terms (e.g., dangin, umah madauh) are often used elliptically to denote specific places; and, as others have noted (e.g., Vickers 1991), time is commonly marked with reference to significant events (e.g., births, deaths, otonan, major Ceremonies, "manis'; as in, 'gas ontonan bli[n]é, 'when your older brother had his otonan ceremony'). Insofar as the idea of 'community' may be given a positive critical meaning, it is at least in part constituted by the commonality at once presupposed and reiterated - i.e., expressed and performatively called into being through the ongoing use of these shared points of reference.

\section{Language: Direct Speech}

As we saw briefly in the opening exchange between Dani and her mother, direct speech is often employed in the course of recounting past events. This seemed more pronounced among the older cohort, who, perhaps not coincidentally, were also less experienced with 'literate' forms of communication. ${ }^{17}$ Indeed,

16 I recall, for example, trying to follow a story being told by a neighbor that involved three separate people whom she simply called 'Wa'. As I learned later, a local friend who'd accompanied me on the day had no difficulty in distinguishing them - and this was, she astutely explained, on the basis of shared pretext that I lacked. I've heard similar complaints of incomprehension from women recently married into the banjar from other parts of the island.

17 Of the five women participating in this initial series of conversations, only Dani's mother was willing to describe herself as able to read and write. One of her elder aunts had completed SD, and acknowledged basic reading and writing skills. The other three had no formal schooling, and claimed to be illiterate (I. buta huruf). This is potentially one of the more interesting, and yet difficult, points in an emerging argument-one for which Sweeney's 
almost entire accounts of prior events may be reported in direct speech, not unlike that sometimes used by the clown servants in dramatic performance (i.e., B. ngojah, in contrast to ngartiang/ ngartos). Here, for example, Dani's paternal aunt by marriage recounts her reasons for not daring (B. sing bani) to remove the IUD. Following a brief exchange with another member of the family, in which she explained why she was recording the conversation, Dani returned to repeat her question. Direct speech is in blue.

Dani ......né matakon Wa, kan... pi- ...now I was asking her, right... dan Wa maKB Wa ora[ha]ng when you were using the IUD 'ked jani sing maelus 'ndén... ['KB'] you said you've not taken takone kéto... it off till now... [I was] asking about that...

Wa Tari (J)aji ping! 'Pang 'da ja-e... Oh my! Better not to... if, if for yan, yan 'paminné yan embus instance... I were to take it off... 'to Wa nyeh ja-é.

I'd be really scared to.

Dani Ada 'engkén bi(i)n kéto? And why’s that again?

Wa Tari 'Paminné... 'aji ping... 'pang Fer instance... oh my... better 'da ja... 'né ja... 'jak-a Mbok not to... I'd gone with Mbok M., M. danginé 'jak maburu 'kén from east of here, to labor with timpalné... "Ba makelo, em- her friends... "It's been a long bus... 'nak $\underline{\mathrm{KB}}$ mapréksa 'nak time, just take off that IUD, get a embus, "nak embus," kétoang check-up, take it off, take it off." 'ja...nyakguguajak makejang That's what they said... so she paras... orah-orahina ngem- trusted (gugu) the lot of those bus 'kén timpalné. "'Wak[e?] stone [workers]... was told to "ba suud me... méns, embus take it off by her friends. "You're nah," kéto. Jeg embus-a lang- done menstruating, take it off," sung pendarahan, langsung like that. So she took it off and ngamin $^{18}$ sing 'nu. 'To 'ba, started to hemorrhage straightWa sing bani. away, and straightaway she was gone. That's it, I don't dare.

Dani 0 , kéto... $\quad \mathrm{Oh}$, is that so...

Wa Tari Ae. Yep.

(1987) study of orality and literacy in Malay is directly pertinent (see below).

18 Ngamin. I.e., B. ngambahin ( $、$ ambah). 
As often the case with the others, Wa Tari's use of direct speech was only very briefly marked by the phrase kétoang ' $j a$, which I glossed very loosely as 'that's what they said' (cp. similar uses of B. abet-né, below). ${ }^{19}$ Here utterances are quoted as if they will be recognized as reported speech; and usually it seems no special effort is made to attribute the speech to a particular person-as we'll see repeatedly in the more extended excerpt below.

\section{From a Convesation with Wa Céng}

The following excerpt is taken from a conversation between Dani and one of her paternal aunts, Wa Céng, who was approximately 58 years old at the time of the recording. Wa Céng never attended school, and claimed not to be able to read or write.

Dani had begun by asking how her aunt had first learned of the KB program, and when she began to use contraception. As with many others of her generation, Wa Céng's story would suggest that her first encounter with $\mathrm{KB}$ came uninvited. Some 18 months after the birth of her second child, ${ }^{20}$ she had experienced an abnormally strong blood flow (I. pendarahan) that continued beyond her menstrual period. So she went to Sanglah Hospital in Denpasar for treatment. There the doctor gave her what was probably a ' $D \& C^{\prime}$, after which he inserted an IUD. ${ }^{21}$ Wa Céng recalled that she had begun having pains in her lower abdomen (B. sisik) less than a month after the procedure, and so hitched a ride (B. numpang) to see a doctor in Abian Kapas. ${ }^{22}$ She explained that she could have been treated by a midwife (I. bidan) at the local Puskesmas, but chose to take the longer trip in order to see the doctor. The following excerpt recalls her experience in Abian Kapas.

Having discussed details of the story with other members of

19 This might be compared with the use of 'like' to introduce direct speech in colloquial American English (e.g., 'And she was like, “I'm outa here!"').

20 This was recalled with reference to a third otonan; “...mara maumur telung oton Mbok A.-e 'gas Wa pendarahan 'to." (Wa Céng's reference to Mbok A. in the third person presumably takes up the point of view of her interlocutor, Dani, for whom Wa Céng's daughter would indeed be addressed as 'elder sister', or Mbok.).

21 It is unclear whether the IUD was requested, or even if Wa Céng gave her consent.

22 As she pointed out, no one had motorbikes in those days ("...pidan sing ada 'nak ngelah montor-e, Honda sing ada "nak ngelah dini."). 
the family, and checking them against the birthdates of her children, I believe these events probably took place sometime in 1978-79. It should also be noted that some of what Wa Céng said can only be worked out with reference to later parts of the conversation-for instance, that it was a book (lines 34-5) that the two nurses were looking through, when, earlier (line 28-9), she had said they were 'searching' (B. alih-alih) for her name. Much of the account is related in direct speech; Wa Céng's own words as she recalls them appear in BLUE; the doctor's words are in GREEN; the nurses' words are in RED.

\section{A Working Transcript: Fear and Loathing in Abian Kapas}

Line Speaker Transcript Gloss Annotations

01 Dani Men suud 'to... 'éng- So after that... how did Dani (D) brings the kén Wa... maksud you.... I mean... what conversation back 'Dék-e... keluh-e ené sorta complaints did ya to Wa Céng (WC), suud nganggo $\mathrm{KB}$ 'to have after using $\mathrm{KB}$ ? following a brief exkéngkén? change with her son and daughter-in-law.

Keluh. See below.

02

Wa
Céng

03

Dani

'ing, bias sing 'éngkén... 'ling big deal... once I was nganggo suntik 'to 'ba on the injections it was sing “éngkén. no big deal.

Sing... maks
WC misunderstands D's question. dék suud nganggo was the implant... (i.e., masang... IUD)

After putting it on?

Céng
Suud masang 'to?
Here the distinction is between ' $\mathrm{KB}$ suntik' (injections) and 'KB pasang' (IUD).

\begin{tabular}{|c|c|c|c|}
\hline $\begin{array}{l}\text { Wa } \\
\text { Céng }\end{array}$ & Suud masang 'to? & After putting it on? & $\begin{array}{l}\text { The term pasang is } \\
\text { used very broadly for } \\
\text { anything appended, } \\
\text { affixed or added-onto } \\
\text { things so diverse as } \\
\text { bodies, buildings and } \\
\text { written letters (see } \\
\text { Fox 2016). }\end{array}$ \\
\hline $\begin{array}{l}\text { WC's } \\
\text { son \& } \\
\text { daught- } \\
\text { er-in- } \\
\text { law }\end{array}$ & [inaudible] & [inaudible] & $\begin{array}{l}\text { Wa Céng's son and } \\
\text { daughter-in-law in- } \\
\text { terject to correct her } \\
\text { earlier misunder- } \\
\text { standing. }\end{array}$ \\
\hline
\end{tabular}

[inaudible] 


\begin{tabular}{|c|c|c|c|}
\hline Line & Speaker & Transcript & Gloss \\
\hline 06 & $\begin{array}{l}\text { Wa } \\
\text { Céng }\end{array}$ & $\begin{array}{l}\text { Suud masang KB 'to? } \\
\text { Uh... sakit! Kéné Wa... } \\
\text { sisik Wa 'to sakit... } \\
\text { 'to Wa, pe(n)darah 'to } \\
\text { 'kondén maKB, kéto } \\
\text { 'to toh. }\end{array}$ & $\begin{array}{l}\text { After putting on the } \\
\text { IUD? Oh... it hurt! } \\
\text { Like this I... my bel- } \\
\text { ly }{ }^{23} \text { hurt... it did, there } \\
\text { was bleeding before us- } \\
\text { ing the } \underline{\mathrm{KB}} \text {, there was. }\end{array}$ \\
\hline 07 & Dani & Suud 'to sisik sakit? & $\begin{array}{l}\text { After that your belly } \\
\text { hurt? }\end{array}$ \\
\hline 08 & $\begin{array}{l}\text { Wa } \\
\text { Céng }\end{array}$ & $\begin{array}{l}\text { Ae sisikné sakit... 'ba } \\
\text { kéto mapréksa Wa ka } \\
\text { Abian Kapas, oraha-a } \\
\text { 'ing cocok maKBé... }\end{array}$ & $\begin{array}{l}\text { Yep it hurt... after that } \\
\text { I went to Abian Kapas } \\
\text { for a check-up, was told } \\
\text { the KB wasn't the right } \\
\text { thing... }\end{array}$ \\
\hline
\end{tabular}

09 Dani Sing cocok maKB Wasn't the right thing, D repeats WC's repasang... the IUD... mark, specifying to confirm that it was the 'KB pasang' (IUD) that wasn't the right thing.

10 Wa Ae. "Sing cocok maKB Yep. "The IUD isn't the It isn't yet clear that it Céng pasang, "Buk." Kéto right thing, Ma'am," is the two nurses that "bet 'né. that's what they said. are speaking here (in red).

"'Buk 'mbus dumun "Let's remove it, The doctor isn't nggih," kéto "bet 'né... Ma'am," that's what he yet named as the said...24 speaker; but D and other members of the family suggested this was who was speaking at this point (in green) - as evidenced inter alia by his respectful mode of address (e.g., $n g$ gih); see below.

"Nggih," kéto mé- "Yes." Indeed that's... WC also speaks formang... kéto "ba. that's how it was [i.e., I mally, seemingly was sick]. differentiating her exchange with the doctor from how she was addressed by the nurses. 

Wa maan opak-a 'di I was scolded there in was interpreted by 'bian Kapas... oraha-a Abian Kapas... they Dani and others as Wa, "Dua tahun sing said to me, "Two years bisada, "moreover, in mapasang." wearing [the IUD]." addition'; 'lagi pula'.

14

"Tiang sing...

mapasang "I was fitted..."

Sing. Emphasizing the preceding term; not negation. Cp. Indonesian kan.

"Ada dua tahun, 'Buk." "It's been two years, Ma'am."

Ah kéto 'bet né. Laadné So that's what they WC seems to be go“ije 'Buk mepasang, said. Before that, ing back to add a de'Buk?”

"Where'd you have it tail from before the fitted, Ma'am?" last remark.

"Di sanglah," ora[ha]ng "At Sanglah," is what Wa kéto. I said.

Dani Ahem... Ahem...

“"Ah 'né 'Buk, sing “Oh, I see Ma'am, you WC appears to mistaén mepasang "to..." were never fitted..."

speak in reporting the dialogue ('never fitted'), and then corrects herself ('never had a check-up'; in the next line).

'Ba kéto... 'betné... Then... she said... uh... "Sing taén uh... "Never had a mapréksa..." 'to "bet- check-up..." was what né. she said.

"Yén mapréksa... tiang "As for a check-up... 'aja tiang sing taén it's true I've never mapréksa mai..." "ba come in for a checkkéto, "Tapi yan tiang up..." then I said, "But "nak mara... uh... t(u) I've only just [started ara ada tahun... 'ling on KB]... uh... it's not tiang ma... mapréksa been years... since I've toh..." had a check-up..."

"Apa sing ora[ha] "Whadya mean you ng 'Buk? Ada 'Buk never, Ma'am? You've mapréksa mai... néé been in for a check"ba ada." up... it's right here." 


\begin{tabular}{|c|c|c|c|c|}
\hline Line & Speaker & Transcript & Gloss & Annotations \\
\hline 23 & & $\begin{array}{l}\text { Ali[hi]n-ali[hi]n 'ba } \\
\text { kéto 'to... ora[ha]ng } \\
\text { Wa sing ada maprék- } \\
\text { sa... t[ua]ra taén ada } \\
\text { mapréksa KB ditu } \\
\text { toh... }\end{array}$ & $\begin{array}{l}\text { And then she started } \\
\text { looking through (the } \\
\text { book)... after I said I'd } \\
\text { not had a check-up... } \\
\text { never had a KB check- } \\
\text { up there... }\end{array}$ & $\begin{array}{l}\text { See lines } 34-5 \text { speci- } \\
\text { fying that it's a book } \\
\text { they're examining. }\end{array}$ \\
\hline 24 & Dani & Opak misi toh? & And scolded besides? & \\
\hline 25 & $\begin{array}{l}\text { Wa } \\
\text { Céng }\end{array}$ & Opak-a Wa, ‘ba kéto... & $\begin{array}{l}\text { I was scolded, after } \\
\text { that... }\end{array}$ & \\
\hline 26 & Dani & Orahanga mapréksa... & $\begin{array}{l}\text { Told to go for a check- } \\
\text { up... }\end{array}$ & $\begin{array}{l}\text { D. seems to be car- } \\
\text { rying the story for- } \\
\text { ward. }\end{array}$ \\
\hline 27 & $\begin{array}{l}\text { Wa } \\
\text { Céng }\end{array}$ & $\begin{array}{l}\text {...uh, ora(ha)ng Wa, } \\
\text { Wa [pra 'li?] ditu... } \\
\text { sing taén mapréksa... } \\
\text { Wa mula sing taen... }\end{array}$ & $\begin{array}{l}\text {...uh, as I'd said, I'd } \\
\text { [?] never been there for } \\
\text { a check-up... I really } \\
\text { never had... }\end{array}$ & \\
\hline 28 & & $\begin{array}{l}\text { “Nak ada abulan kan } \\
\text { sing ragané mepréksa... } \\
\text { tapi sisikné sakit.” Kéto } \\
\text { abetné, kéto abetné. } \\
\text { Uh... alihin-alihin-né... } \\
\text { "Masak! 'Buk sing taén } \\
\text { mapréksa... Masak! } \\
\text { Anu, anu, anu...”" }\end{array}$ & $\begin{array}{l}\text { "It's been a month and } \\
\text { you've not had a check- } \\
\text { up... but yer belly } \\
\text { hurts." That's what she } \\
\text { said, that's what she } \\
\text { said. Uh... and then just } \\
\text { kept looking [through } \\
\text { the book]... "Nonsense! } \\
\text { You've never been for a } \\
\text { check-up... Nonsense! } \\
\text { Um, um, um..." }\end{array}$ & $\begin{array}{l}\text { See lines } 34-5 \text { on 'the } \\
\text { book'. }\end{array}$ \\
\hline
\end{tabular}

Kéto 'ba 'betné. Alih- That's what they said. Kadék Tani is Wa alihin-né, jeg ada 'nak Looking through, and Céng's official name. madan Kadék Tani, sure enough there was (Both, though, are kéto toh. 'Ba kéto... someone called Kadék pseudonyms.) [inaudible] opaka Wa Tani, right there. And kéné... "Né, "né, "né... then [inaudible] I was kudang taun... kené scolded like, "Here, kudang taun..." Kéné here, here... how many liu Wa baang munyi 'ba years... here, how kéto. many years..." Then they really let me have it after that. 


\begin{tabular}{|c|c|c|c|}
\hline Line Speaker & Transcript & Gloss & Annotations \\
\hline 30 & $\begin{array}{l}\text { "'Buk, 'nak tiang 'nak } \\
\text { 'ten taén... 'ten... } \\
\text { ma... ma... ma... ma- } \\
\text { pasang makelo kéto } \\
\text { Buk... mapréksa meri- } \\
\text { ki, 'ten tiang, dija [ja?] } \\
\text { tiang sing taén," kéto } \\
\text { 'bet Wa. }\end{array}$ & $\begin{array}{l}\text { "Ma'am, I've really } \\
\text { never... not been... } \\
\text { been... been... wear- } \\
\text { ing it for a long time, } \\
\text { ma'am... come in for a } \\
\text { check-up, not me, I've } \\
\text { never been anywhere } \\
\text { for a checkup," that's } \\
\text { what I said. }\end{array}$ & \\
\hline 31 & $\begin{array}{l}\text { "Apa sing? Ené 'ba ada } \\
\text { buktin-né dini. 'Né Ka- } \\
\text { dék Tani, 'ba ada buk- } \\
\text { tin-né 'né!" }\end{array}$ & $\begin{array}{l}\text { "Whadya mean never? } \\
\text { here's the proof right } \\
\text { here. Here's Kadék } \\
\text { Tani, the proof's right } \\
\text { here!" }\end{array}$ & \\
\hline
\end{tabular}

Ah liu "ba ajaka dua So the two of "em had Only later in the conWa, ngopak toh... bin- really given me a scold- versation did it bejep 'né... 'ba makelo ing... and just then... come clear that this is Wa 'ba opak-é... jeg they'd been scolding the doctor (in green). jelék-jelék sajan mu- me for some time... nyi-né! 'Ba kéto ada ja they'd said such awful teka 'nak muani 'sik. things! But then along Kéto "to. "'Engken 'né came a man. Just like 'Buk." Kéto 'bet-né. that. "How's it going, ma'am?" That's what he said.

"Pak, tiang kono... "Sir, I'd like to ... kéné laadné... tiang what'd happened ma... mapasang laadné was... before I'd... di Sanglah," "ba kéto, been fitted before at "Kuala sisik tiangé Sanglah," and then (I sakit. Tiang mapréksa, said) "But my belly 'ba mai 'gas telun, hurt. I'd had a checktiang 'ba mai, mapréksa up, came in three days sing kéto. Mangkin ago, I'd already come kono ['keneh?] 'mbus in, I'd gotten the checktiang... 'ba kéto... jeg up. Now I'd like to reopaka tiang... ora[ha] move it... and then... ng tiang... kudang... I was scolded... I was dua tahun sing taén told it'd been... how mapréksa tiang? Soal- many... two years I'd né... sing ada mapasang gone without a checkdua tahun."

up? The thing is... I've not been wearing [the IUD] for two years." 


\begin{tabular}{|c|c|c|c|c|}
\hline Line & Speaker & Transcript & Gloss & Annotations \\
\hline 34 & & $\begin{array}{l}\text { "Apa sing,"orahang-a. } \\
\text { “Né ‘ba... "né ‘ba buk- } \\
\text { tinné..." Gablég ketang } \\
\text { biin buku 'to di méja } \\
\text { toh, kan negak 'to, ada } \\
\text { mejané... ga-ba-lag! } \\
\text { ketang bukuné. }\end{array}$ & $\begin{array}{l}\text { "Whadya mean 'no"?," } \\
\text { she said. "Here's the... } \\
\text { here's the proof..." And } \\
\text { she slammed that book } \\
\text { back down, smack on } \\
\text { the table. Just sitting } \\
\text { there, eh, there was } \\
\text { the table, slammed the } \\
\text { book-wham! - down. }\end{array}$ & \\
\hline 35 & & $\begin{array}{l}\text { "Bukuné... "né ada } \\
\text { buktinné... "né... "ba... } \\
\text { "ba... ah... dua ta- } \\
\text { hun sing taén... ma... } \\
\text { ma-anu. }{ }^{25} \text { Ngorahang } \\
\text { ma... mapasang mara... } \\
\text { masang..." }\end{array}$ & $\begin{array}{l}\text { "The book... here's the } \\
\text { proof... here... it's... } \\
\text { it's... already... ah... } \\
\text { two years and never a } \\
\text { whadya-call-it... Say- } \\
\text { ing it's only just been... } \\
\text { been fitted..." }\end{array}$ & \\
\hline 36 & $\begin{array}{l}\text { daugh- } \\
\text { ter-in- } \\
\text { law }\end{array}$ & [inaudible] & [inaudible] & $\begin{array}{l}\text { Discussing some- } \\
\text { thing with her hus- } \\
\text { band, WC's son. }\end{array}$ \\
\hline
\end{tabular}

37 Wa "Tiang mara satu bulan, "I've only had it one Céng kéto." Wa beneh-beneh month." I was really adéng-adéng kéto "ba trying to speak cauWa mamunyi. tiously.

'Ba kéto abetné muani After that the man said, 'to, “'Jati, 'Buk, kénten "Truly, ma'am, is that laadné, 'Buk?" how it went, ma'am?"

“"Ten, Pak. Tiang ada “No, Sir. I really hadn't 'ten mula mapasang. been fitted (with the Tiang mara 'gas 'né IUD). I was only fitmapasang, tiang maan ted just recently, and makérét. "Né beneh- had come to be scraped beneh toh." out. ${ }^{26}$ That's the truth."

40 'Kéto 'ba... kebit, ke- And after that... turnbit, kebit, kebit... két(o) ing, turning, turning, ang buku 'to kené né turning... the pages muani 'to. Binjep "né of that book, the man jeg... 'nak 'ling 'Siman did. And but a moment madan kéto, alamat-né later... that lady from Badung.

Kesiman with the same name, her address in Badung.

'Ba kéto kéné-ang, After that he said, “'Buk, 'buk... 'ling "Ma'am, where are you dija 'niki, 'Buk?” Kéto from, Ma'am?" That's 'bet muani 'to. what the man said. 
Line Speaker

42

43 Wa's [inaudible]

son

44 Wa

Céng
['Ba raga anu 'to (?)]

Kebit-kebit-a, 'ba med Flipped through (the 'to... binjep kauk 'tas book) again, got bored né 'jak dua 'to. Kéto with that, and then abetné... "Buk," kéto called over to the two abetné, "meriki du- of them. That's what he mun." did... "Ladies," he said, "come here, please."

"Kéngkén? Kéngken?" "What is it? What is "To abetné... "nu ke- it?," they said... and nyat masih-e. still harshly as ever, too.

[?]

Annotations

"Tiang 'ling Batan "I'm from the ward of Raga. Why the apparNangka 'nika, Banjar Batan Nangka, Batan ent shift in $1^{\text {st }}$ person Nangka, Pateluan," Nangka, in Pateluan" I pronoun? Cp. lines $46 \& 51$, below.

WC's son speaks loudly, telling someone that they're discussing KB.

Unclear. Is the raga in reference to $\mathrm{WC}$ herself? If so, this seems rather an odd shift in register. Or could it refer to her 'body'? Cp. line 51, below.

"'Buk, "niki pelih ala- "Ladies, this is the mat niki, "Buk." Kéto wrong address, ladies." abetné.

That's what he said.

Ketoang 'ne luh-luh 'to, And the women said, "Kéngkén? Kéngkén?" "What is it? What is it?"

"Néné anu... Badung "This one's um... she's Pointing to the wom'né, 'né 'nak 'ling 'Si- from Badung, it's a per- an's name in the book, man né, anteg 'ked son from Kesiman, even who, though having banjarné "ba misi," including the name of the same name as kéto abetné, ah... kéto her banjar," that's what WC, is listed as living abetné... ahh... kéto he said, ah... that's in Kesiman, Badung. abetné. what he said... ahh... that's what he said.

What are we to make of these repetitions? (E.g., kéto abetné; cp. lines 29, 40, 44.) They seem to come at points of heightened emotion. 


\begin{tabular}{|c|c|c|c|c|}
\hline Line & Speaker & Transcript & Gloss & Annotations \\
\hline 50 & & [inaudible] & [inaudible] & \\
\hline 51 & & $\begin{array}{l}\text { Jelék-jelék Wa baang } \\
\text { munyi 'gas 'to kan inget } \\
\text { ragaé... "Kéné, kéné, } \\
\text { kéné," kéto ‘betné. }\end{array}$ & $\begin{array}{l}\text { I got such an ugly ear- } \\
\text { full that day, I sure do } \\
\text { remember it. "It's like } \\
\text { this, like this, like this," } \\
\text { they said. }\end{array}$ & $\begin{array}{l}\text { Ragaé. Usage un- } \\
\text { clear; compare line } \\
46 \text {, above. }\end{array}$ \\
\hline 52 & & [inaudible] & [inaudible] & \\
\hline 53 & & $\begin{array}{l}\text { Akhir-né ya opak-a... } \\
\text { 'ba kéto... 'kuala 'tas } \\
\text { 'ilang ya langsung, nyak } \\
\text { 'ing ya ngembus-e... }\end{array}$ & $\begin{array}{l}\text { In the end they got in } \\
\text { trouble... after that... } \\
\text { but then they disap- } \\
\text { peared straightaway, } \\
\text { so they couldn't help } \\
\text { remove it. }\end{array}$ & I.e., remove the IUD. \\
\hline
\end{tabular}

54 Dani [inaudible] [inaudible]

Dani asks Wa's son a question.

55 Wa Nah... 'to... lantas-é So... then... after that Céng 'to 'ba opak ya begitu they got in trouble, and 'antasang, binjepné so right after that the kéné 'to baan bapak 'to, man said, "Ma'am, my "Buk, tyang ampunan, apologies, ma'am, I "buk, ngidih sinam- beg your forgiveness," pura," kéto "ba. "Sing like that. "They didn't bali[hi]n anu-né... on- inspect the thingee... yang," kéto abetné... [i.e., the book] all of Jeg "ba madanné Ka- it," he said... Her name dék Tani, kéto adanné was Kadék Tani, that masih... kéto. was her name too.

56 Dani Ohoh, patuh adanné Oh, she just had the 'gén... same name...

57 Wa Adanné patuh ya. Sing Her name was the same. Céng ya bali[hi]n-a alamat né They didn't check the 'ija... kéto toh. Jek 'ba address... I'd already oraha... saja ya... "nak told 'em... it truly anu, "nak 'to toh. was... ya know... that person there.

58 ' $\mathrm{Nu}$, masih Wa I'd also said I'd not, not ngora[ha] sing, sing been... not ya know, ma... ma-anu, saja been fitted, truly not... toh... sing... sing ma- not been fitted. I'd not pasang, kéto. T[ua]ra been wearing it for ada mapasang mekelo, long. And then... finalkéto toh. Binjepné... ly they got in trouble... akhir-né 'to bin opak with him. e... kéné baan 'né. 


\begin{tabular}{|c|c|c|c|}
\hline Line Speaker & Transcript & Gloss & Annotations \\
\hline 59 & $\begin{array}{l}\text { "Mara Buk mepasang } \\
\text { kéné ‘jak... "ten 'Buk } \\
\text { cocok niki?" } \\
\text { abetné. }\end{array}$ & $\begin{array}{l}\text { "You've recently had it } \\
\text { fitted, and it doesn't fit } \\
\text { right?" That's what he } \\
\text { said. }\end{array}$ & \\
\hline 60 & $\begin{array}{l}\text { "Sira ngembus, Pak?" } \\
\text { "to. }\end{array}$ & $\begin{array}{l}\text { "Who "ll take it out, } \\
\text { Sir?" }\end{array}$ & \\
\hline 61 & $\begin{array}{l}\text { "Sira 'gen dadi... tiang } \\
\text { dadi" kéto 'betné. }\end{array}$ & $\begin{array}{l}\text { "Anyone can do it... I } \\
\text { can do it," like that, he } \\
\text { said. }\end{array}$ & \\
\hline 62 & $\begin{array}{l}\text { “Oh, Ibuk ento 'éngkén } \\
\text { men 'nika, Pak... tiang } \\
\text { terus jelék-jelék-jelék } \\
\text { ya tiang baang munyi?" }\end{array}$ & $\begin{array}{l}\text { "Oh, now what about } \\
\text { those ladies, sir... I was } \\
\text { being given such an } \\
\text { ugly earfull?" }\end{array}$ & \\
\hline 63 & $\begin{array}{l}\text { “Ma’af ya, 'buk... 'buk, } \\
\text { tiang ngidih sinampura, } \\
\text { nggih,” kéto abetné. }\end{array}$ & $\begin{array}{l}\text { "I beg your forgiveness, } \\
\text { I'm sorry, ma'am... } \\
\text { Yes, I didn't know } \\
\text { about this," that's what } \\
\text { he said. }\end{array}$ & \\
\hline
\end{tabular}

The story Wa Céng told emphasizes her vulnerability before an opaque bureaucracy - a distant power that was nonetheless capable of sustaining an invasive grip on her body. To review briefly, she had experienced an abnormally strong blood-flow lasting beyond her usual menstrual period roughly 18 months after the birth of her second child. She went to Sanglah hospital in Denpasar for treatment, where she underwent what was likely a D\&C. Following the procedure, she was also fitted with an IUD. However, within a month, she began to have abdominal pain. So she went to the hospital in Abian Kapas for a check-up. There Wa Céng was mistaken for someone else using the same name ('Kadék Tani'). On account of mistaken identity, the two nurses on duty erroneously assumed she had been fitted with an IUD some two

23 Sisik. Lower belly, just below the belly button.

24 Dani's attribution of several of these statements is based on Wa Céng's subsequent remarks, and discussion with both Wa Céng and other members of the family.

25 Presumably 'mapréksa'.

26 This term (makérét) is often used in reference both to 'D\&E' (dilation and evacuation) and D\&C (dilation and curettage) procedures. Its is more generally used of 'grinding', or the sound that it makes. 
years beforehand. And they berated her for going so long without a check-up. The more she protested, the angrier they became, until a male doctor came along and asked what was happening. On inspecting the book of records, he recognized the mistake. It turned out the other woman listed in the book, also called Kadék Tani, was from a different part of the island. The nurses were chided for their carelessness, and the doctor offered to remove the IUD himself, apologizing for how she had been treated.

This synoptic account is perhaps somewhat easier to follow than the transcript itself. And this is at least in part due to the way in which the story was recounted. In Wa Céng's conversation with Dani, events were not related in strictly chronological order (see, e.g., lines 6, 16); there is repetition, both in specific turns of phrase, and the events themselves; sentences often stop and start abruptly, changing subject or topic; and the narrative is frequently carried forward by direct speech, often with scant indication of who is speaking (e.g., lines 10, 11, 41). The latter tendency seems especially pronounced in moments of heightened 'drama', as is the rapid repetition of words and short phrases (e.g., 'kebit, kebit, kebit, kebit...'; 'kéto abetné, kéto abetné...'; 'kéné, kéné, kéné...'; 'jelék, jelék, jelék...'). Although each of the recorded conversations differs from the others in many respects, these characteristics are common throughoutparticularly, it seems, with Dani's older interlocutors.

So, what might we learn from an analysis of Wa Céng's style of speaking, and of recounting past events? Is there, for instance, a link between what she said and how she said it? Or would this already be to presuppose a dubious distinction? Given Wa Céng's limited schooling, and claims of illiteracy, might we extrapolate from Sweeney's (1987) argument for a non-literate style of composition and experience? Very briefly, Sweeney had extrapolated from the scholarship on the Greek 'literate revolution' (Havelock 1963, 1982; Lord 1976 [1960]) to suggest that, while the introduction of literacy has had an important and demonstrable effect on the way Malays think, speak and write, there is a 'residual orality' evident in many aspects of Malay life. This is premised on the idea that the practices associated with 'literacy' bring with them new styles of thought and speech, characterized, e.g., by analyticity and a separation of the knowing subject from the objects and circumstances in which acts of knowing take place (cp. Ong 1958). He argued that this 
distantiation and analyticity sit in sharp contrast to the sensibilities of non-literate communication, as exemplified by oral composition in shadow theatre and related performative styles. He described the latter as characterized by 'distinctive motifemic patterning on the level of plot, character typing, themes, parataxis, repetition, copiousness, parallelisms, formulas, and formulaic expressions' (1987: 84). It may be worth considering the extent to which these and related elements may be discerned in the way older Balinese recount past events; and, conversely, how this might differ from the ways younger people - who have undergone years of formal education, and involvement with varyingly 'literate' media engage both with the past and their efforts toward the future. ${ }^{27}$

\section{Etiquette, judgment, community}

Looking more closely at the transcript, Wa Céng's story was predominantly recounted in colloquial 'low' Balinese, the familiar style of speaking characteristic of day-to-day life among one's close associates, particularly in and around the ward..$^{28}$ But it also incorporated elements of Indonesian and a more formal register of Balinese. This conversational mélange is quite common, and is recognized as such (e.g., as bahasa gado-gado, or bahasa campuran). As is often the case, Wa Céng's narrative included Indonesian words for which there was no easy Balinese equivalent (alamat, $K B$, méja), as well as numbers (satu, dua), and various other terms (terus, mémang, langsung, begitu) and expressions (ma'af; masak!). However, in addition to these 'purely' Indonesian terms and phrases, she also used narrative 'linking' words that brought together a standard Indonesian base with a Balinese affix (e.g., soal-né; akhir-né) - which, again, is not uncommon.

As the primary language of articulation, colloquial Balinese linked together descriptions of events and reports on direct speech,

27 There is a problematic tendency toward essentialization ('the literate mind' etc) both in Sweeney's writing and the scholarship on which he was drawing. However, the more general point regarding 'media' and the ordering of experience is highly suggestive.

28 In passing it should also be noted that this demotic style of speaking is frequently deployed on radio and television, and in popular dance drama, to exemplify an idealized vision of 'traditional' Balinese life-a bucolic idyll set against the backdrop of an increasingly modern Indian conception of ancient Indic high culture. 
as addressed to Dani-and presumably, to some extent, for my ear. However, beyond this, the direct speech itself marks differences of status and refinement, as indicated by subtle shifts in register. While the nurses speak coarsely, 'giving out words' (B. baang munyi) that are 'ugly, ugly, ugly!' (B. jelék, jelék, jelék!), the doctor recognizes her predicament and addresses her sympathetically, even going so far as to apologize (e.g., "Ma'af ya, 'buk... 'buk, tiang ngidih sinampura, $n g g i h, ")$. As for Wa Céng's account of her own speech, the use of polite pronouns (B. tiang; I. Pak) and simple markers of respect (B. nggih) might be seen as directed to situating her in a suitably deferential - and so respectable - position vis-à-vis the doctorand so, potentially, 'polite society' at large. This is not to suggest that Wa Céng was arguing in a considered fashion for a particular vision of collective life. But, rather, what I wish to suggest is that her linguistic nod to social grace - and to the judgment it seemed to entail - may have presupposed a specific ideal of communityone exemplified by the status markers and sor/singgih distinctions loosely sprinkled through the remarks she attributed to the doctor and herself. Assuming for the moment this were the case, we might then ask a series of new questions. For instance, what sort of ideal was this? And where else might we find it exemplified (e.g., in traditional dance drama, or shadow theatre)? What kinds of agency would it afford people like herself? How, specifically, was it violated by her mistreatment at Abian Kapas? And, however subtle, to what contemporary transformation - e.g., of her own situation, or that of her family and close associates - might her implicit judgment regarding this past experience have been directed?

\section{Fear and the Family}

As an institutionalized ideal, family was a source of fear in the early days of $\mathrm{KB}$ - something to which one was subjected through procedures about which little information was directly available. The initial conversations with the older cohort would suggest that women in Batan Nangka were afraid to 'use $\mathrm{KB}^{\prime}$ (B. ma-KB)some even hiding in the pig sties to avoid detection by the roving midwife. Indeed the terms used in reference to those who were 'caught' by the tukang $K B$ were the same words one uses of a pig 'seized' for slaughter (e.g., ngejuk, juk-juk). But women were often equally afraid to stop using the IUD once they had begun, several 
citing stories of ensuing infertility, hemorrhaging and death (see, e.g., Wa Tari's remarks, above). Although I gather the term 'patient' (I. pasién) was not used in this connection, it would have been an accurate description of the form of agency embodied by women at the time. And, for good reason, few dared to complain.

Note for instance how Wa Céng carefully avoided criticizing the $\mathrm{KB}$ program directly - and this despite her difficulties with the IUD, and her all but Kafkaesque experience in Abian Kapas. This reluctance is evident to varying degrees in each of the recorded conversations with the older cohort. Dani's grandmother ('Dadong') offers an illustrative example. Reflecting on her experience with the IUD, and the early days of KB in Batan Nangka, Dadong recalled a series ailments that included a white discharge (B./I. putihan), a fleshy build-up around the IUD (B. tumbuh daging), and significant weight loss (merag-merag). Yet, in spite of her own account - which had linked these events to one another, and to the insertion of the IUD - she demurred at Dani's subsequent effort to elicit criticism of the KB program itself-or even reports of criticism from others. The following excerpt came as they discussed the door-to-door visits from the tukang $K B$.

Dadong Alih 'jak mai 'kén kéto tukang $\underline{\mathrm{KB}} \ldots$

Dani Oooh... 'ling ditu tekan KB-e...

Dadong Pemerintah-e mula ngongkon ma- $\underline{\mathrm{KB}}$... 'pang bedik jleme-é.

Dani Ooh... 'ing ada keluhan apa... artin 'né...

Dadong 'Pang 'da ja-e! Dadong ngelus... 'nak sing ada ulian' $\underline{\mathrm{KB}}$ sing-e... 'nu masih mesuang putihan kéto... 'nu mesuang putian 'to... 'nak ulian lén-e... 'to tumbuh daging...
Those tukang KB came a-looking just like that [i.e., door-todoor]...

Oh... so that's how $\underline{\text { KB }}$ came...

Indeed the government commanded we use $\underline{\mathrm{KB}}$... so there'd be fewer people.

Oh, so there weren't any complaints... ya mean...

I should hope not! I removed (it)... but not on account of the $\underline{\mathrm{KB}}$ (i.e., the IUD), no... still there was also the white stuff coming out... the white stuff was still coming out (but) it was on accounta something else... that fleshy growth... 
Family planning was widely understood to be a government initiative, ${ }^{29}$ and this was a woman who had only recently survived the purges of 1965-66. Again, Dadong recalled the three ailments - the discharge, the fleshy growth and the weight loss - as being related to one another; and this relationship was made explicit in the course of recounting her early experience of KB. Yet she resisted the idea of a causal connection to the IUD, and expressed dismay (B. 'Pang 'da ja-e!) at the thought of 'complaints' or 'symptoms' (I. keluhan) arising directly from 'the KB' (B. 'KB-e').

When I queried Dani's use of the term keluhan, she initially explained that she'd meant "symptoms (I. gejala) or irritations (I. kesal)... when you go to the doctor you're asked what's bothering you (I. keluhannya), for instance a bad stomach ache, with persistent diarrhea... that's an example of keluhan." But on further reflection she agreed there may have been some ambiguity here. On reviewing the recording, both she and a middle-aged neighbor, Putu, saw in Dadong's response a reticence to complain about government programs. When I asked Putu whether he thought this fear (B. jejeh) would have been based on a specific experience, he said he could not say for certain. But he then recounted how one of his neighbors had moved away from Batan Nangka because he was too scared (B. nyeh) to come home. Putu went on to describe a conversation he'd had with his neighbor - now living in another part of the island - around the time of the 2009 presidential elections. He had asked his neighbor why some 40 years later he was still afraid to return to Batan Nangka. The exchange, he said, went something like this:

$\begin{array}{lll}\text { Putu } & \text { Adi nyeh? } & \text { Why (are you) afraid? } \\ \text { Neighbor } & \text { Takut. } & \text { (Coz I'm) scared. } \\ \text { Putu } & \text { Adi takut? } & \text { Why (are you) scared? } \\ \text { Neighbor } & \text { Nyeh. } & \text { (Coz I'm) afraid. }\end{array}$

It seemed Putu's point was that, whether due to a specific event or otherwise, the experience of 1965-66 left the older generation profoundly shaken, and afraid to criticize openly anything that

29 In fact, the situation was rather more complicated, relying on funding, logistics and personnel from a combination of state and non-government organizations (see Niehof \& Lubis 2003; Parker 2003). 
might be related to the government. The recorded conversations would appear to support this strongly. So, given its localized origins in fear, how did the family become an object of desire for younger Balinese living in Batan Nangka?

\section{From Fear to Desire... and Anxiety}

Between the early 1970s and 80s, the women of Batan Nangka were subjected to 'the family' as an array of instruments, institutions and procedures. Standing (or lying down) before the doctors, nurses, midwives and tukang $K B$, they were afforded little of the knowledge and capacity for transformation - of themselves and the world around them - that we tend to associate with the term 'agency'. Yet this is not to suggest they were powerless to resist, or to evade, the concerted effort to transform them into docile mothers and housewives, and so members of a governable population. To say nothing of the simple fact of their survival, and moments of levity, the sharp wit and criticism characteristic of many of the older Balinese women with whom I've had the privilege of working are eloquent testimony to the but partial success - and so partial failure - of 'the small, happy and prosperous family' as a normative principle. ${ }^{30}$ So too are the countless Nyomans, Komangs, Komings and Ketuts, who stand as evidence of Balinese thinking and acting beyond the mantra of dua anak cukup, laki perempuan sama saja. ${ }^{31}$ Put simply, the drive for hegemony was not entirely successful.

Can the same be said for more recent generations? However provisionally, the recorded conversations with the younger cohort seem to suggesta high degree of ambivalence. Wehave seen examples of fear in Dani's conversations with older members of her extended family. They were afraid to use KB; they were afraid to stop using $\mathrm{KB}$; and they were afraid to complain. Under the circumstances, this probably made very good sense. Fear may also figure in how younger Balinese now think about family and their plans for the future. But it is likely a rather different sort of fear-perhaps more

30 Here I use the term 'normative' advisedly. The phrase in question is norma keluarga kecil, bahagia dan sejahtera (see Newland 2001).

31 To be clear, my point is not that having more than two children is an expression of women's freedom, as against state institutional oppression. Rather, I would suggest it points to the limits of the familyist ideal-at least in earlier generations. 
in line with that treated in the opening frames of the advertisement for the Andalan IUD. Dani's conversations with younger Balinese touch on concerns for health and physical discomfort, as well as the possibility of gaining weight, and so becoming unattractive to a prospective partner. But the heavy shadow of state violence is conspicuously absent.

Perhaps in its place we find, instead, a series of comparatively novel anxieties organized around the ideals of individuality and consumption. Without wishing to draw any firm conclusions at this point, it seems younger Balinese are acutely attuned to the precarity of their future, as determined by their choice of partner, their performance in school and their ability to earn and save money. In contrast to the early days of $\mathrm{KB}$, the 'small, happy and prosperous family' is now predominant as both the means toward, and embodiment of, the good life. Its pursuit is characterized by a language shot-through with loanwords from English, including such things as planning, studi, bisnis, komitmén, target, gol, suksés, mental yang baik and ekonomi yang kuat. ${ }^{32}$ The individualizing character of these goods and virtues is seized upon with enthusiasm-offering pride in accomplishment and perceived opportunities for greater self-determination. But, so described, this 'small family' ideal also sets many younger Balinese at odds with the domestic circumstances in which they find themselves-living, as most in Batan Nangka are, in larger houseyards with their extended families. Set against this more proximate situation, fantasies of romance, elegance and individual accomplishment are played out, among other places, through social media (e.g., Facebook, Vine, Instagram), where posed photographs and expressions of sentimentality prevail. ${ }^{33}$ My initial impression is that the styles of self-presentation in play - and the aspirations they embody - differ from anything their parents and grandparents would have sought, experienced or even been able to recognize. Working out where some of the key differences lie, and how they relate to one another, is where the project is heading.

32 Note how these terms differ from older styles of planning and preparation (on which, see Hobart 2000: 270-1). This, too, is an issue to which I hope to return in some detail.

33 This might be approached in terms of Morson's (1994) notion of 'sideshadowing', an idea Mark Hobart recommended to me more generally on reading an earlier draft of this article. 


\section{Appendix: Indonesia's Family Planning 'Success Story'}

In very general terms, the ideals and institutions driving Indonesian 'state familyism' were motivated by a desire to curb population growth by controlling birth rates. The underlying premise was a causal link between population control and economic development. This link was initially forged at the level of international aid policy in the early 1950s, though it would not become a part of Indonesian plans for national development until some time later.

From the late 1950s through the early 70s the general sensibility was Malthusian, and for a time self-avowedly so. ${ }^{34}$ Among policymakers, aid workers and politicians there was a working consensus that a reduction in 'positive checks' on population growth - such as war, famine and disease - was resulting in societies unable to provide for themselves. And, in the absence of "preventative checks' - such as birth control and the postponement of marriage - it was thought the situation would only worsen. Family planning was touted as the obvious way forward. The aim was to reduce birth rates - and therefore population growth - through medical contraception, birth spacing, and education aimed at increasing the age of first marriage. Again, as with the diagnosis, the solution was fundamentally Malthusian.

Despite eventually becoming a family planning 'success story', Indonesia was seen to be ambivalent with regard to the grounding philosophy of population control. Though the history is undoubtedly more complicated than it is often made to appear (see Hull \& Hull 2005), the country's early resistance to family planning is frequently attributed to Soekarno's 'natalist' insistence on a positive relationship between population growth and economic development.

Although there were isolated, clinic-based programs supported by various NGOs and international aid agencies as early as the late 1950s, a concerted Indonesian family planning program did not get underway until 1964. Indeed it was not until three years later, in 1967, that Soeharto signed the UN Declaration on Population. And it would be an additional two years after that, in 1969, that the formal link between population and economy would be recognized

34 Things became more complicated after the 1974 'World Population Conference' in Bucharest. 
at the level of national development policy with the first Five-Year Development Plan (Repelita I, 1969). Repelita I made the argument for birth control with explicit reference to population growth and its presumed effect on economic development. However, the program itself was listed under the heading of healthcare for mothers and newborn children-and so birth control was, at least on paper, kept at something of a remove from planned development. ${ }^{35}$

During the period of the first Repelita (1969-1974) family planning was carried out through a limited clinic-based program based in the more densely settled areas of Java and Bali. It was with the second Five-Year Development Plan (1974) that family planning became formally linked to population control and economic development. This brought together, at the level of policy, the two key elements of what the later Foucault theorized in terms of biopower: the sciento-bureaucratic management of population and the medical regulation of bodies (see Newland 2001). These were in turn linked to the promulgation of what I would describe as new forms of both social and practical reasoning anchored in the ideal of the 'small, happy and prosperous family'. This included:

- The isolation of the nuclear family as the primary social and administrative unit;

- Prescibed limitations on the size of the family-two parents, two children;

- The model of childhood as gender-neutral and graduated (I. bayi, balita, anak-anak, remaja), with state-mandated benchmarks each step of the way;

- New division of labor as exemplified, e.g., in schoolbooks and on television - father works and provides 'guidance' (national familyism is a scale of forms); mother is a homemaker and primary socializer of children; children go to school;

- New organization of space-shared marital bedroom; children's individual bedrooms; public male space versus private female/children's space;

35 The initial reticence to link birth control to national development has been attributed to 'cultural' factors, and more specifically to the objections of Islamic clerics (Sarwono 2003: 29; Hugo et al. 1987). Again, the reality is presumably somewhat more complex. 
- New relationship between parents as members of a monogamous social unit, displacing older patterns of working, confiding and socializing;

- New relationship between parents and children (invest in children's education; children 'help at home', but do not contribute to the household economy);

- New linkage between the isolated family unit and the state, both at the institutional level (development programs) and practical reasoning (setting of personal and collective goals, decision-making, planning for the future);

- New model of political solidarity, in which an abstract fealty to the nation replaces particularist relations of alliance and patronage;

- New complex of virtues - obedience, hygiene, ind ustriousness, commitment to progress, age- and gender-specific normalcy, self-sacrifice, patriotism, monotheism;

- New spiritual ideal within which the individual is responsible for its own well-being in this world and beyond, anchored in a socio-soteriological theory of God, morality, the soul, rebirth and salvation.

These new ideals have been cultivated through a range of 'formal' and 'informal' institutions of 'guidance' (I. bimbingan) and 'education' (I. pendidikan) - from the Family Welfare Organization (PKK) and elementary school to television programming and more traditional media, such as shadow theatre (B./I. wayang kulit) and light opera (B. arja). In more recent years these ideals have also served as the foundation for promulgating new forms consumption, as evidenced by the prominence of 'the family' in advertising. On television, radio and the Internet, consumers are hailed as housewives, fathers and children, and more insidiously still as 'men', 'women' and 'youth' desirous of a freedom that is now articulable in opposition to the constraints of family roles and obligations, which today it seems may - at least sometimes - be taken for granted. 


\section{Works Cited}

Austin, J.L. 1975. How To Do Things with Words; The William James Lectures Delivered at Harvard University in 1955. Second edition. Oxford and New York: Oxford University Press.

Barthes, R. 1972. 'Myth Today'. Mythologies. Selected and translated by A. Lavers. New York: Hill \& Wang.

Errington, J. 1998. Shifting Languages: Interaction and Identity in Javanese Indonesia. Cambridge: CUP.

Fabian, J. 1983. Time and the Other; How Anthropology Makes its Object. New York: Columbia University Press.

Fabian, J. 1990. Power and Performance; Ethnographic Explorations through Proverbial Wisdom and Theater in Shaba, Zaire. Madison, WI: University of Wisconsin Press.

Fox, R. (forthcoming, a) 'Etymology is Not Destiny: Moments of Translational Indeterminacy on an Indonesian Island'.

Fox, R. (forthcoming, b) More Than Words: Transforming Script, Agency and Collective Life in Bali. Ithaca, NY: Cornell University Press.

Fox, R. 2016. 'The Meaning of Life... or, How to Do Things with Letters'. In: Fox, R. \& A. Hornbacher (eds.) The Materiality and Efficacy of Balinese Letters: Situating Scriptural Practice. Leiden: Brill.

Geertz, H. \& C. Geertz .1975. Kinship in Bali. Chicago: University of Chicago Press.

Havelock, E.A. 1963. Preface to Plato. Cambridge, Mass.: Harvard University Press.

Havelock, E.A. 1982. The Literate Revolution in Greece and Its Cultural Consequences. Princeton: Princeton University Press.

Hobart, M. 1979. A Balinese Village and Its Field of Social Relations. Unpublished Doctoral Dissertation, University of London.

Hobart, M. 2000. After Culture: Anthropology as Radical Metaphysical Critique. Yogyakarta, Indonesia: Duta Wacana University Press.

Hugo, G.J. et al. 1987. The Demographic Dimension in Indonesian Development. Singapore: Oxford University Press.

Hull, T. \& V.J. Hull. 2005. 'From Family Planning to Reproductive Health Care: A Brief History'. People, Population, and Policy in Indonesia. Jakarta \& Singapore: Equinox Publishing. Page 1-69.

Korn, V.E. 1932. Het Adatrecht van Bali. Second Edition. The Hague: Naeff. 
Lord, A.B. 1976 [1960]. The Singer of Tales. New York: Atheneum.

Morson, G.S. 1994. Narrative and Freedom: The Shadows of Time. New Haven: Yale University Press.

Newland, L. 2001. 'The Deployment of the Prosperous Family: Family Planning in West Java'. Feminist Formations. 13(3): 22-48.

Niehof, A. \& Lubis, F., eds. 2003. Two is Enough: Family Planning in Indonesia Under the New Order 1968-1998. Leiden: Koninklijk Instituut voor Taal-, Land- en Volkenkunde. Pages 1-18.

Ong, W.J. 1958. Ramus and Talon Inventory: A Short-Title Inventory of the Published Works of Peter Ramus (1515-1572) and Omer Talon (Ca. 1510-1562) in Their Original and in Their Variously Altered Forms. Cambridge, Mass.: Harvard University Press.

Parker, L. 2003. From Subjects to Citizens. Copenhagen: NIAS Press..

Sarwono, S. 2003. 'Family Planning in Indonesia Under the Old Order'. In Niehof, A. \& F. Lubis (eds) Two is Enough: Family Planning in Indonesia Under the New Order 1968-1998. Leiden: KITLV. Pages 19-30.

Shiraishi, S.S. 1997. Young Heroes: The Indonesian Family in Politics. Ithaca, NY: Cornell University Press.

Sweeney, A. 1987. A Full Hearing. Orality and Literacy in the Malay World. Berkeley \& Los Angeles: University of California Press.

Vickers, A. (1991) 'Ritual Written: The Song of the Ligya, or The Killing of the Rhinoceros'. In Geertz, H. (ed) State and Society in Bali: Historical, Textual and Anthropological Approaches. Leiden: KITLV.

Zurbuchen, M. 1984. 'Contexts and Choices: Spoken Indonesian in Bali'. In Morgan, S. \& Sears, L.J. (eds.) Aesthetic Tradition and Cultural Transition in Java and Bali. Madison, WI: Center for Southeast Asian Studies, University of Wisconsin. Pages 247-66. 